\title{
Algerian Yeast Strains: Isolation, Identification and Production of Single Cell Protein from Whey with Strain Candida kefyr
}

\author{
Salima Kebbouche-Gana and Mohamed Lamine Gana
}

\begin{abstract}
In this study, few samples than soft and baked cheese, yogurt, cow's milk, pasteurized milk and cheese whey were collected from dairy industries in the city of Boumerdes. The samples were cultured on yeast extract glucose chloramphenicol agar (YGCA) media. Twenty yeast strains were isolated from the culture. Tenof theses strains were identified by their morphological and physiological properties. Betagalactosidase activity in the yeast strains showed that a strain Candida kefyr designated as LP1 had highest enzyme activity (up to $5000 \mathrm{EU} / \mathrm{ml}$ ). To investigate the effectiveness of batch submerged fermentation of the yeast $C$. kefyr in cheese whey, we found that this strain have highest level of single cell protein (SCP), production (up to $19 \mathrm{~g} / \mathrm{l}$ dry mass cell). The isolated yeast strain was examined for his ability in reduction of the chemical oxygen demand (COD). So, the results demonstrated a high level of reduction.
\end{abstract}

Index Terms-Beta-galactosidase, Candida kefyr, single cell protein, whey.

\section{INTRODUCTION}

The existence of pollution problems associated with agro-industrial wastes, costlier treatment options and increased need to save valuable resources have forced to encourage the utilization and bioconversion of waste into high value industrially useful products. Many by-products of the food industry are discarded in nature and thus constitute a source of pollution because of their quantity.

So, whey water, the greenish translucent liquid obtained after the precipitation of cheese is a very good source of lactose, proteins, vitamins and minerals. When, whey water is disposed to the environment without pretreatment, it pollutes the water bodies by increasing the biological oxygen demand in the range of 38,000 to $46,000 \mathrm{ppm}$ as opposed to $200 \mathrm{ppm}$ in case of sewage [1].

Approximately 1.50, 000 tonnes of Edam cheese and 2 million tonnes of whey are produced annually in Algeria. The recycling of whey is becoming valid and viable economic activity and is increasingly mentioned as a solution to some of the most serious problems of mankind. So, the huge amounts of whey considered as "waste" can potentially be used to produce various value added products like animal feeds, biofuels, enzymes, chemicals, etc. . . . However, the bioconversion of whey into single cell protein, (SCP), or ethanol has been performed in several countries [1], [2].

SCP could be produced from whey, with employing of

Manuscript received February 7, 2014; revised March 18, 2014.

Kebbouche-Gana Salima is with the University M'Hamed Bougara Boumerdes, Algeria (e-mail: kebboucheslima@yahoo.fr). yeasts from different genera including Kluyveromyces, Candida, and Trichosporon capable of metabolizing lactose [3]-[6]. The most important characteristic of these single-celled organisms is their high protein content, ranging from about 40 to $80 \%$ of their dry weight on a crude protein basis.

In this study, some lactose fermentative yeasts strains were isolated and identified and the objectives of this study were to evaluate the capacity of the isolates to assimilate lactose, to investigate the effectiveness of batch submerged fermentation of the yeast in cheese whey for the production of SCP. Additionally; the COD removal was evaluated too.

\section{MAterials AND METHOdS}

\section{A. Sampling and Isolation of Yeast Strains}

Several samples including soft and baked cheese, yogurt, cow's milk, pasteurized milk and cheese whey were collected from dairy producing factories in Algiers.

The samples collected in sterile $500 \mathrm{ml}$ bottles and transferred to laboratory in a cooler box. The yeasts were enriched by inoculation of $10 \mathrm{ml}$ (or $10 \mathrm{gr}$ ) of the sample in $90 \mathrm{ml}$ of yeast extract glucose chloramphenicol agar (YGCA) medium, pH 4.5 containing $0.1 \mathrm{~g} / \mathrm{l}$ chloramphenicol. The incubation was performed at $28^{\circ} \mathrm{C}$ for $24 \mathrm{~h}$ with constant shaking of $120 \mathrm{rpm}$.

The yeast cells in media were examined using optical microscopy. The yeast strains were isolated on spread plates of Sabouraud chloramphenicolagar after making serial dilutions. The plates were incubated at $28^{\circ} \mathrm{C}$ for $48-72 \mathrm{~h}$. Colonies with distinct morphological differences were selected and purified by streaking on potato-dextrose agar (PDA) [7].

\section{B. Measurement of Beta-Galactosidase Activity}

According to Gunther and Burger [8], O-Nitrophenol $\beta$-D-Galactopyranoseide (ONPG) assay was applied for calculation of beta-galactosidase enzyme activity in the yeast strains as previously reported [8]. Briefly; the isolated strains were inoculated in YPD medium and incubated at $28^{\circ} \mathrm{C}$ for 12-18 h. One ml of yeast cultures (approximately $10^{8}$ cells) at $\mathrm{OD}_{600}$ was span down. Then, the cells were washed in $1 \mathrm{ml}$ cold $\mathrm{Z}$ buffer $\left(0.06 \mathrm{M} \mathrm{Na}_{2} \mathrm{HPO}_{4}, 0.04 \mathrm{M} \mathrm{NaH} \mathrm{PO}_{4}, 0.01 \mathrm{M}\right.$ $\mathrm{KCl}$ and $\left.0.001 \mathrm{M} \mathrm{MgSO}_{4}\right)$. The activity of the beta-galactosidase enzyme was measured in the presence of ONPG at $\mathrm{OD}_{420} \mathrm{~nm}$ and the Miller unit was calculated as follows: 
Units $=1000 \times \mathrm{OD}_{420} /$ volume $(1 \mathrm{ml}) \times$ time $(\min ) \times \mathrm{OD}_{600}(1)$

\section{Identification of the Yeast Strains}

To identify the yeast strains capable of lactose fermentation, the isolated yeasts were cultured in Durham tubes containing $2 \%(\mathrm{w} / \mathrm{v})$ lactose [9]. Then, the positive yeast strains for lactose fermentation were identified using the standard taxonomic key outlined according to Barnett et al. [10]and Yarrow [11]. Experimental results of physiological tests were analyzed by the software package of Barnett et al. [12].Growth assays were repeated 3 times in 3 replicates.

\section{Cultivation of Selected Strain on Whey Medium}

Growth experiments were conducted in $5 \mathrm{~L}$ stirred tank bioreactor with a working volume of $3.8 \mathrm{~L}$ was employed in this experiment. $3 \mathrm{~L} \mathrm{ml}$ of sterilized cheese whey medium was transferred to the bioreactor which was then inoculated with $300 \mathrm{~mL}$ of microbial yeast suspension. The bioreactor was maintained in conditions: $28^{\circ} \mathrm{C}, \mathrm{pH} 4.5$ (by addition of 1 $\mathrm{M} \mathrm{HCl}$ and $1 \mathrm{M} \mathrm{NaOH}$ throughout the fermentation), aeration $1 \mathrm{vvm}$, and $400 \mathrm{rpm}$. After inoculation the bioreactor was set to work for $22 \mathrm{~h}$ and samples were drawn every $2 \mathrm{~h}$. To eliminate whey's proteins, it was clarified by heating at $100^{\circ} \mathrm{C}$ for $15 \mathrm{~min}$ after adjusting the $\mathrm{pH}$ to 4.6 (isoelectric $\mathrm{pH})$. After settling of the whey's proteins, the supernatant was ultra filtered and the greenish yellow liquid was sterilized at $115^{\circ} \mathrm{C}$ for $10 \mathrm{~min}$. We also supplemented the deproteined whey with $0.5 \%(\mathrm{w} / \mathrm{v})$ ammonium sulfate as the nitrogen [13].

\section{E. Analytical}

The cell dry weight was determined asprevious work [14], [15]. Aliquot of the culture media was centrifuged at 5000 rpm for $15 \mathrm{~min}$, after washing the biomass with Ringer serum; it was precipitated for a second time before measuring dry weight, followed by drying of the cells at $105 \pm 1^{\circ} \mathrm{C}$ for $2-3 \mathrm{~h}$.

In addition, the optical density of the culture was measured at $620 \mathrm{~nm}$ in a spectrophotometer. The lactose concentration was determined using sugar analyzer (YSI Model 27). Chemical oxygen demand was determined according to the procedures described in the Standard Methods for the Examination of Water and Wastewater [16]. The concentrations of ethanol in the samples were determined by high-performance liquid chromatography (HPLC) (Shimadzu Corp) using a Rezex ROA column (Phenomenex) at $63^{\circ} \mathrm{C}$ and $4 \mathrm{mM} \mathrm{H}_{2} \mathrm{SO}_{4}$ as eluent at flow rate of $0.6 \mathrm{ml} / \mathrm{min}$, equipped with a refractive index detector. Samples were $\mathrm{pH}$-adjusted to 2.0-2.3 and filtered through a $0.45 \mu \mathrm{m}$ membrane prior to injection into the vials.

\section{RESULTS AND DISCUSSION}

\section{A. Phenotypic Characterization of Isolates}

Pure cultures of 20 morphologically distinct yeast isolates dairy producing factories in Algiers were selected on the basis of the colony morphology. This study revealed that 10 out of 20 isolates were capable of growing on lactose. The characterization of these yeasts was based on conventional methods established by Barnett et al. [10], Yarrow [11] and Barnett et al. [12]. These methods rely on the definition of various morphologic and physiological characteristics of yeasts. Rapid methods currently marketed (API $50 \mathrm{CH}$ ) may validly, in some cases, replace the conventional approach of identification, for example yeasts encountered in hospitals. However, they are proving inadequate for dairy and food products [17].

Morphological criteria include the appearance of the cell, the aptitude of filamentation and sporulation, and the appearance of the liquid and solid media. Physiological criteria include the assimilation of a nitrogen compound, the assimilation and fermentation of different carbon sources, and the resistance to certain unfavorable environmental conditions (presence of antibiotic or high sugar concentration). According to Barnett et al. [10] data, 439 species of yeasts belonging to 57 different genera, were counted and are identified by these methods. Moreover, in the simplified dichotomous keys of the classification of yeasts, it is established that most of the yeasts present two modes of asexual divisions [18].

So, the first group included the genus Schizosaccharomyces which is divide by scissiparity, and the second group is composed of most of the other yeasts that breed vegetatively by budding. Among the isolated yeasts, the asexual reproduction of the strains VLV, FR1 and FR4, respectively obtained from cow's milk, hard cheese and soft cheese, is characterized by the scissiparity.

However, according to Lodder [18] and most authors, only the Schizosaccharomycoideae are characterized by dividing by binary fission. According to the same author, this family includes a single genus. It is the Schizosaccharomyces genus, and is represented by somespecies like S Japonicus, S pombe, Smalidevorans and Soctosporus.

However, the isolated Strains FR1, FR4 and VLV have broadly the same morphological and sexual characteristics of the Schizosaccharomyces genre. Indeed, Lodder [18] and several authors characterize this genre by whitish cream colored colonies on a solid medium, the cells' shape is elongated, ovoid and spherical, and they shred to give a true mycelium that fragments into arthrospores.

Sexual reproduction is present, the spores are of a globular form - their number varies from 4 to 8 spores depending on the species. Nitrates are never assimilated by the genus Schizosaccharomyces. The assimilation and fermentation of various sugar compounds vary from one species to another. Comparing our results with those reported in data [10], [11], [12], [18], we can see that the yeast strains FR1, FR4 have the same characteristics as the strain Schizosaccharomycesoctosporus, this latter species was isolated by Lodder [18], from sugar cane molasses. It is well spread in sweet food, but rarely in dairy products.

The presence of Schizosaccharomycesoctosporus in cheeses used as sample isolation is possibly due to his unexpected presence in the milk powder, the latter is a staple 
ingredient of recombined milk used for the cheese formulations in the Algerian dairies.

However, the yeast strain VLV showed the same characteristics as the species Schizosaccharomycesmalidevorans. The presence of this yeast in a dairy product such as cow's milk has not been previously demonstrated. The natural biotype of this strain is not known [18]. This is yeast that has been isolated for the first time from grapes [19]. It is characterized by its inability to assimilate maltose, but easily grows on glucose.

Thus, among the ten yeast strains isolated, the strains FR4, FR1 and VLV belong to the genus Schizosaccharomyces and respectively to the S.octosporus and S.maldevorans species.

Furthermore, Graham [19] claims that when yeast is very infrequently isolated, it can be assumed that it is rare in nature or possibly undefined. In addition, it should be noted that most of the yeasts generally have a particular geographical location.

Finally, among the 10 strains of yeasts isolated, there are three yeast species to adopt a scissiparity mode of division, among the remaining strains none of them are divided by bipolar budding and can therefore not be one the following genera: Kloeckera, Wickerhramii, Nadsonia and Hanseniaspora cited by Hupert [20].

Besides, all our isolated strains breed vegetatively by multipolar budding. Therefore, the yeast genera mentioned above are to be excluded.

According to Lodder [20] and Barnett et al. [21] data, the criterion sporulation is the basis of the dichotomy between Ascosporogenous yeasts (Fungi imperfecti) when physiological tests do not allow, by themselves, to distinguish these large types of yeast. Indeed, some anascosporogenic yeasts exhibit identical characteristics to those of ascosporogenous species.

Thus, the study of the sporulation ability allows distinguishing between the isolated strains of yeasts VL1, VY1, FR2, FR3, and VKL1 and the strains LP1 and VY2; the latter two strains have no ability to form ascospores or other form of sporulation. Thus, the strains VY2 and LP1 have similar characteristics with the Candida genera, Cryptococcus and Torulopsis described by Lodder [18] and other authors. In order to distinguish between both the genera Cryptococcus from Torulopsis, the same author propose to include in the genus Cryptococcus all species that can assimilate inositol as the single carbon source. In addition, he also adopted the assimilation of inositol test and has considered it as an important criterion in distinguishing between the both genera Cryptococcus and Torulopsis [18].

In fact, Cryptococcus genus assimilates only inositol. So, Torulopsis species are unable to assimilate this carbon compound. Yet, comparing our results (Table I), we note that the strains LP1 and VY2 assimilate inositol and other carbon sources.

About the both genera Candida and Torulopsis, it is often difficult to distinguish between them because they have much in common. That is why some authors adopted the filamentation test or the formation of pseudomycelium as a distinctive criterion. Indeed, most Candida species are characterized by their ability to form a well-developed pseudo mycelium, while, it is not presentorrudimentaryin thegenusTorulopsis.

However, yeast strains LP1 and VY2 form an abundant pseudomycelium. Given this range of distinctive criteria, we could identify the strains LP1 and VY2 and join them to Candida genus. According Lodder [18] in the genus Candida the cells are globular, ovoid, cylindrical or elongated but never ogival and dived by budding and the filament cells give an abundant pseudomycelium. Thus defined by these authors, $C$. kefyr and $C$. pseudotropicalis have the same characteristics as the isolated yeast strains LP1 and VY2.

TABLE I: IDENTIFICATION OF YEASTS ISOLATED FROM DAIRY PRODUCER IN THE CITY OF ALGIERS

\begin{tabular}{|c|c|c|c|c|c|c|c|c|c|c|c|}
\hline 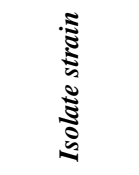 & $\frac{1}{3}$ & $\underset{c}{ \pm}$ & $\underline{a}$ & $\bar{a}$ & $\underset{>}{2}$ & 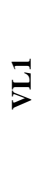 & $\ddot{x}$ & $\underset{\widetilde{a}}{\tilde{I}}$ & $\frac{\vec{B}}{8}$ & $\bar{\lambda}$ & \\
\hline glucose & + & + & + & + & + & + & + & + & + & + & \\
\hline galactose & + & + & + & + & + & + & + & - & - & - & \\
\hline saccharose & + & + & + & + & + & + & + & - & - & - & $z$ \\
\hline melibiose & - & - & - & - & - & - & - & - & - & - & E \\
\hline maltose & - & - & - & - & - & - & - & + & + & - & 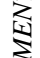 \\
\hline lactose & + & + & + & + & + & + & + & - & - & - & 蛋 \\
\hline trehalose & - & - & - & - & - & - & - & - & - & - & \\
\hline cellobiose & - & - & - & - & - & - & - & - & - & - & \\
\hline glucose & + & + & + & + & + & + & + & + & + & + & \\
\hline galactose & + & + & + & + & + & - & - & - & - & - & \\
\hline saccharose & + & + & + & + & + & + & + & + & + & + & \\
\hline melibiose & - & - & - & - & - & - & - & - & - & - & \\
\hline maltose & - & + & + & + & - & - & - & + & + & - & \\
\hline lactose & + & + & + & + & + & + & $\begin{array}{l}+ \\
+\end{array}$ & - & - & - & \\
\hline trehalose & - & + & + & + & - & - & - & - & - & - & \\
\hline arabinose & - & - & - & - & - & - & - & - & - & - & $\gtreqless$ \\
\hline xylose & + & + & - & - & + & - & - & - & - & - & $\underset{\exists}{\mathbb{3}}$ \\
\hline cellobiose & - & - & - & + & + & - & - & - & - & - & $\bar{\pi}$ \\
\hline nitrate & - & - & - & - & - & - & - & - & - & - & \\
\hline inositol & $\begin{array}{l}n \\
d\end{array}$ & $\begin{array}{l}n \\
d\end{array}$ & $\begin{array}{l}n \\
d\end{array}$ & + & + & $\begin{array}{l}n \\
d\end{array}$ & $\begin{array}{l}n \\
d\end{array}$ & $\begin{array}{l}n \\
d\end{array}$ & $\begin{array}{l}n \\
d\end{array}$ & $\begin{array}{l}n \\
d\end{array}$ & \\
\hline $\begin{array}{l}\stackrel{\tilde{U}}{\tilde{J}} \\
\tilde{\Xi}\end{array}$ & 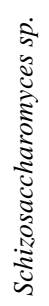 & 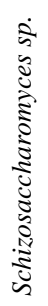 & 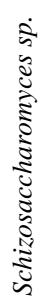 & 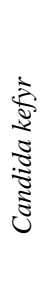 & 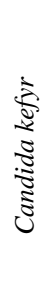 & 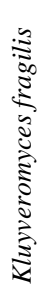 & 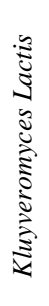 & 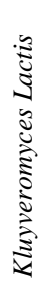 & 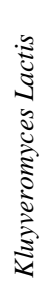 & 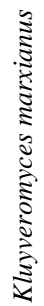 & \\
\hline
\end{tabular}


The distinction between the two first, lies in their ability to assimilate xylose, a sugar easily used by C.pseudotropicalis.

According to the results, the LP1 and VY2 strains, respectively isolated from pasteurized milk and yoghurt are linked to the Candidakefyr species. Wijeyaratne [5] reported in his works an abundant presence of this yeast in dairy products such as milk and cheese, it is part of their normal microbial flora, considering its ability to use lactose, dominant sugar in milk.

In their study, Mlimbila et al. [22] demonstrates that diverse yeast species existed in the examined Tanzanian traditional (mtindi) and industrially fermented milk (yoghurt) in which mtindi from Mwanza contains the most diverse yeast flora using ribosomal DNA-Polymerase Chain Reaction (PCR) amplification and sequencing of the domains D1/D2 of the 26S rRNA gene. The identified yeasts were Candida tropicalis, C. pararugosa, Candida sp. and Pichiasp.

Regarding VL1, VY1, FR2, FR3 and VKL1 strains, in addition to their asexual multiplication which occurs by multipolar budding, they have the ability to sporulate and form ascospores, thus, the sporulation allows to exclude the anascosporogenic yeasts and to distinguish them from the previously described species.

According to some authors, such as Lodder [18], Pichia and Kluyveromyces genera have many properties in common with the isolated yeast strains VL1,S the ascospores are spherical, ovoid and their number varies from 1 to 16 ascospores per ascus. Nitrates are not assimilated by this genus. The membership of each of the isolated strains (VL1, VY1, FR2, FR3 and VKL1) to the corresponding species, like kluyveromyces genera, lies in the comparison of the made physiological tests, with those of the kluyveromycesfragilis, kluyveromyceslactis and kluyveromycesmarxianus species [18].

Thesesame species have very similar physiological characteristics. They differ from one another by the following features. The species $K$. lactis easily assimilates trehalose unlike $K$. fragilis and $K$. marxianus which are unable to assimilate sugar. However, according to our results (Table I), the strains FR2, FR3 and VKL1 assimilate well trehalose, therefore, they belong to the species of $K$. lactis. Furthermore, the difference between $K$. marxianus and $K$. fragilis lies in their speed to ferment lactose; indeed, $K$. marxianus species slowly ferment lactose while it is rapidly fermented by $K$. fragilis [18], [23], [24]. The achievement of this test, allowed us to identify the isolated yeast strains VL1 and VY1 and affiliating them respectively to the $K$. fragilis and $K$. marxianus genera.

Nevertheless, according to previous authors, the fungus flora of cheese and some dairy products consists of a yeast population in which the species of the genus Candida and Kluyveromyces are strongly represented. Dairy products are considered as their natural biotopes. To conclude with, we could isolateten different strains of yeasts from used dairy products. These yeasts strains are considered as lactic yeasts. The greater part of them is cultured from whey for the production of single-cell proteins. Yeasts of the genus Schizosaccharomyce sare never used for this purpose, in fact, in stirred liquid culture, these yeasts develop hyphal forms once the medium is depleted of its nutrients.

\section{B. Screening and Kinetic Analysis of SCP Production}

The lactose metabolism by the yeasts was studied by several authors [23], [24]. In this study, 20 yeasts isolates were examined for lactose fermentation ability. Among them, 7 strains (LP1, VY2, VL1, FR3, FR2, VKL1 and VY1) were found capable of lactose fermentation. Enzyme activity of beta-galactosidase in yeast strains was measured. Among 07 yeast strains, the LP1strain (Candida kefyr) was found to have the highest enzyme activity, 5366 unit/ml (Table II) Also the VL1 strain (Kluyveromyces fragilis) and VKL1 strain (Kluyveromyces lactis) were showed high enzyme activity, 5182 and 5020 unit/ml, respectively.

Screening of lactose-fermenting yeast strains has been conducted by Ianieva et al. [23], among 162 strains isolated from various plants and 28 strains isolated from cheese, four yeast strains fermented lactose and were identified as Candida kefyr. The specific $\beta$-galactosidase activity of the studied strains was 1501-2113 IU/g dry biomass. The same authors found that the ability of strains C. kefyr $\mathrm{C} 24$ and C30 to produce ethanol from lactose was significantly inhibited by the increase in substrate concentration $(100 \mathrm{~g} / \mathrm{L})$ [23].

TABLE II: BETA-GALACTOSIDASE ACTIVITY IN THE ISOLATED YEAST

\begin{tabular}{|c|c|c|c|}
\hline \multicolumn{4}{|c|}{ STRAINS } \\
\hline Isolate & Sample & Species & $\begin{array}{l}\text { Beta-galactosi } \\
\text { dase activity } \\
\text { (EU-ml) Using } \\
\text { whey medium }\end{array}$ \\
\hline LP1 & Whey & Candida kefyr & 5366 \\
\hline VY2 & Cow Milk & Candida kefyr & 4832 \\
\hline VL1 & Yogurt & $\begin{array}{l}\text { Kluyveromyces } \\
\text { fragilis }\end{array}$ & 5182 \\
\hline FR3 & $\begin{array}{l}\text { Dough } \\
\text { Baked } \\
\text { Cheese }\end{array}$ & $\begin{array}{c}\text { Kluyveromyces } \\
\text { lactis }\end{array}$ & 4120 \\
\hline FR2 & $\begin{array}{l}\text { Dough } \\
\text { Baked } \\
\text { Cheese }\end{array}$ & $\begin{array}{c}\text { Kluyveromyces } \\
\text { lactis }\end{array}$ & 4009 \\
\hline VKL1 & $\begin{array}{l}\text { Dough } \\
\text { Baked } \\
\text { Cheese }\end{array}$ & $\begin{array}{c}\text { Kluyveromyces } \\
\text { lactis }\end{array}$ & 5020 \\
\hline VY1 & Yogurt & $\begin{array}{c}\text { Kluyveromyces } \\
\text { marxianus }\end{array}$ & 4646 \\
\hline
\end{tabular}

In this study, the results showed that there was a direct relationship between lactase activity and biomass production in cheese whey. Batch fermentation of whey with $C$. kefyr was performed, at $28^{\circ} \mathrm{C}, \mathrm{pH} 4.5$ (Fig. 1) with $\mathrm{pH}$ control. Fig. 1 illustrates the SCP production, lactose utilization, ethanol production and chemical oxygen demand. The low $\mathrm{pH}$ was 
chosen to overcome bacterial contamination.

Lactose utilization started within $8 \mathrm{~h}$, and all lactose was utilized after $16 \mathrm{~h}$. Lag phase in SCP production was observed in this experiment, it lasted 8 hours of time. During the exponential growth phase, the biomass concentration increased exponentially with cultivation time and reached 19 $\mathrm{g} / \mathrm{l}$ and lactose concentration depleted rapidly, however, the stationary growth phase reaching after $14 \mathrm{~h}$ and the lactose was reduced about $87.11 \%$ after $14 \mathrm{~h}$.

In this study, the ultra filtration of the spent culture reduced in an effluent having total COD reductions of $94 \%$. The biomass yield obtained in this case was greater than those reported Torulopsis cremoris and $K$. fragilis and $C$. kefyr and C. valida [25]-[27].

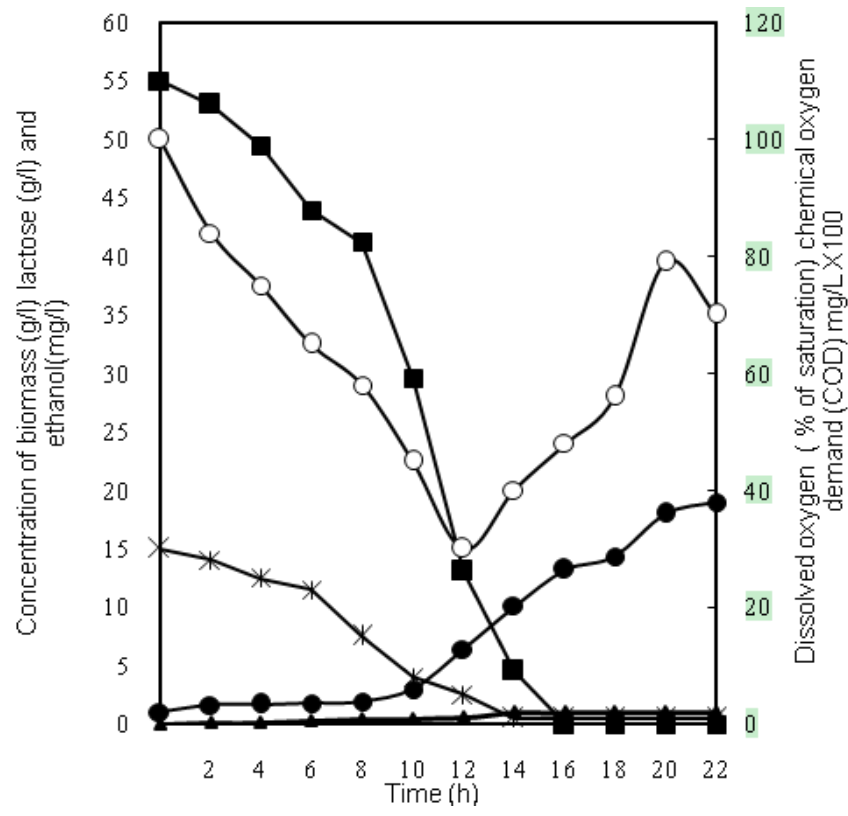

Fig. 1. SCP production during the growth of $C$. kefyr on chess whey: concentration of biomass yield (--), lactose consumption (- --$)$, ethanol production $(--)$, dissolved oxygen $\left(-\mathrm{O}^{-}\right)$and chemical oxygen demand (COD) reduction (-*-).

Increasing demand for protein sources of high nutrition value has stimulated the application of SCP in animal feed. With regards to these results we consider these yeast strains especially to be viable candidates for production of single cell protein from cheese whey. However, the reduction of the COD was studied by some authors such as Yadav et al. [28]. In this study, cell growth reached the end of the exponential phase after 22 hours and within this period most cells achieved COD reduction in Whey medium by $94 \%$ (Fig. 1), the final COD values ranged between from 150 to $100 \mathrm{mg} / \mathrm{L}$ in this batch culture.

\section{CONCLUSION}

To promote high tonnages whey production by fermentation of single-cell protein is one of the most attractive ways. Production of Candida kefyr yeasts for food or feed is a bioprocess already exploited industrially. To be economically competitive, the production of yeast on whey must be performed with a maximum conversion of lactose into biomass with high productivity in a fermentor. Together, the data showed that the isolated yeast strain LP1 could be of valuable application in bioconversion of cheese whey.

\section{REFERENCES}

[1] A. J. Mawson, "Bioconversions for whey utilization and waste abatement," Biores. Technol., vol. 47, pp. 195-203, 1994.

[2] M. I. Gonzales, "The biotechnological utilization of cheese whey," A review, Biores. Technol., vol. 57, pp. 1-11, 1996.

[3] H. Kallel, L. G. Sanchez, J. M. Engasser, and A. Miclo, "Optimisation d'une culture continue de Kluyveromyces fragilis sur ultrafiltrat de lactosèrum. Influence de minéraux et de vitamines sur le métabolisme de la levure," Microbiol Aliment Nutrition, vol. 9, pp. 309-317, 1991.

[4] H.S eiler and M. Busse, "The yeasts of cheese brines," Int. J Food Microbiology, vol. 11, pp. 289-304, 1990.

[5] S. C. Wijeyaratne and A. N. Jayathilake, "Characteristics of two yeast strains (Candida tropicalis) isolated from Caryota urens (Kithul) toddy for single cell protein production," J. Natl. Sci. Found Sri Lanka, vol. 28, pp. 79-86, 2000.

[6] A. R. C Braga, P. A. Gomes, and S. J. Kalil, "Formulation of culture medium with agroindustrial waste for $\beta$-galactosidase production from Kluyveromycesmarxianus ATCC 16045," Food Bioprocess. Technol., vol. 5, no. 5, pp. 1653-1663, 2012.

[7] A. E. Bainotti, J. C. Basilico, and M. S. C. de Mendoza, "Optimizing conditions for the discontinuous production of unicellular protein using whey," Rev. Argent. Microbiol., vol. 19, pp. 1-7, 1987.

[8] E. Gunther and E. Burger, Amethod of manufacturing lactose-hydrolyzed yoghurt by means of beta-galactosidase, Use of enzyme in Food Technology, Paris, 1982.

[9] G. H. Fleet and M. A. Main, "The occurrence and growth of yeasts in dairy products," Int. J. food Microbiology, 4, pp. 145-155, 1987.

[10] J. A. Barnett, R. W Payne, and D. Yarrow, Yeasts: Characterization and Identification, Cambridge: Cambridge University Press, 1990.

[11] D. Yarrow, "Methods for the isolation, maintenance and identification of yeasts," in The Yeasts, a Taxonomic Study, 4th ed., C. P. Kurtzman, J. W. Fell (Eds.), Amsterdam: Elsevier, pp. 77-101, 1980.

[12] J. A. Barnett, R. W. Payne, and D. Yarrow, "Yeast Identification, "PC Program, Cambridge: Cambridge University Press, 1996.

[13] H. Moeini, S. Vallian, and I. Nahvi, "Isolation and Identification of Yeast Strains Capable of Producing Single Cell Protein from Whey in Co-Cultures with Saccharomyces cerevisiae," Iranian Journal of Biotechnology, vol. 2, no. 1, pp. 13-18, 2004

[14] M. Jakobsen and J. Narvhus, "Yeasts and their possible beneficial and negative effects on the quality of dairy products," Int Dairy J., vol. 6, pp. 755-768, 1996

[15] J. H. Litchfield, "Single-cell proteins," Science, vol. 219, pp. 740-746, 1983.

[16] APHA, Standard Methods for Examination of Water and Wastewater, New York: American Public Health Association, 1995.

[17] T. Deák, "Handbook of food spoilage yeasts," 2nd ed. United kingdom: CRC Press, pp. 294-297, 2008

[18] J. Lodder, The Yeast, Amsterdam: North Holland Pub Co., 1970.

[19] H. F. Graham, "Wine yeasts for the future," FEMS Yeast Research, 2008, DOI: $10.1111 / \mathrm{j} .1567-1364.2008 .00427$.

[20] M. Hupert, G. Harper, S. H. Sun, and V. Delanerolle, "Rapid methods for identification of yeasts," J. Clin. Microbiol, vol. 2, pp. 21-34, 1975

[21] J. Barnett, R. Payne, and D. Yarrow, Yeast: characteristics and identification, 3rd ed., Cambridge: Cambridge University Press, 2000.

[22] J. S. Mlimbila, K. M. Hosea, and M. Muruke, "Molecular Identification and Proteinase Activity of Yeasts Isolated From Fermented Milk," International Journal of Diary Science Research, vol. 2, no. 2, pp. 7-14, 2013.

[23] O. D. Ianieva, G. O. Voronina, and V. S. Pidgorskyi, "Isolation and characteristics of the lactose-fermenting yeasts Candida kefyr," Cytology and Genetics, vol. 47, issue 6, pp. 359-365, 2013.

[24] P. M. Guimaraes, J. A Teixeira, and L. Domingues, "Fermentation of lactose to bio-ethanol by yeasts as part of integrated solutions for the valorisation of cheese whey," Biotechnol. Adv., vol. 28, no. 3, pp. 375-384, 2010.

[25] D. Beausejour, A. Leduy, and R. S. Ramalho, "Batch cultivation of Kluyveromyces fragilis in cheese whey," Canadian Journal of Chemical Engineering, vol. 59, pp. 522-526, 1981.

[26] J. H. litchfield, "Single-cell proteins," Science, vol. 219, pp. 740-746, 1983.

[27] M. H. Mansour, A. E. Ghaly, R. M. Ben-Hassan, and M. A. Nassar, "Modelling batch production of single cell protein from cheese whey I: 
Kluyveromycesfragilis growth," Applied Biochemistry and biotechnology, vol. 43, no. 1, pp. 1-14, 1993.

[28] J. S. S. Yadav, J. Bezawada, S. Elharche, S. Yan, R. D. Tyagi, and R. Y Surampalli, "Simultaneous single-cell protein production and COD removal with characterization of residual protein and intermediate metabolites during whey fermentation by K. Marxianus," Bioprocess and Biosystems Engineering, 2013, DOI 10.1007/s00449-013-1072-6.

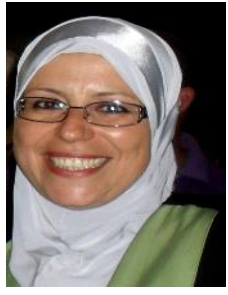

Kebbouche-Gana Salima has obtained PhD from Polytechnic National School University and postdoctoral degree from University of Sciences and Technologies Houari Boumediene Algiers (Algeria). She is the head of team in Laboratory Microbial biodiversity and biotechnology (Bmbeap) in the University M'Hamed Bougara of Boumerdes, 1st November Avenue, 35000 Boumerdes, Algeria. She has published more than 9 papers in reputed journals.

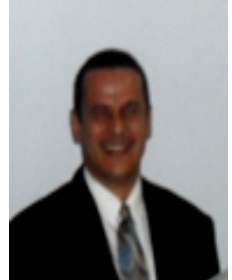

Mohamed Lamine Ganahas obtained $\mathrm{PhD}$ and postdoctoral degree from Polytechnic National School University. $\mathrm{He}$ is the head of Department of Biocorrosion Laboratory in the Research and Development Center, Sonatrach, Avenue 1er Novembre, 35000 Boumerdes, Algeria. He has published also more than 9 papers in reputed journals. 